Columbia Law School

Scholarship Archive

2006

\title{
Public Attitudes About the Culpability and Punishment of Young Offenders
}

Elizabeth S. Scott

Columbia Law School, escott@law.columbia.edu

N. Dickon Reppucci

ndr@virginia.edu

Jill Antonishak

author742105@ssrn.com

Jennifer T. DeGennaro

author742108@ssrn.com

Follow this and additional works at: https://scholarship.law.columbia.edu/faculty_scholarship

Part of the Criminal Law Commons, Criminal Procedure Commons, Juvenile Law Commons, Law and Race Commons, and the Law and Society Commons

\section{Recommended Citation}

Elizabeth S. Scott, N. Dickon Reppucci, Jill Antonishak \& Jennifer T. DeGennaro, Public Attitudes About the Culpability and Punishment of Young Offenders, BEHAVIORAL SCIENCES \& THE LAW, VOL. 24, P. 815, 2006; COlumbia Public LaW Research PAPER No. 07-135 (2006).

Available at: https://scholarship.law.columbia.edu/faculty_scholarship/1456

This Working Paper is brought to you for free and open access by the Faculty Publications at Scholarship Archive. It has been accepted for inclusion in Faculty Scholarship by an authorized administrator of Scholarship Archive. For more information, please contact scholarshiparchive@law.columbia.edu. 


\section{Columbia Law School}

Public Law \& Legal Theory Working Paper Group

Paper Number 07-135

\section{Public Attitudes About the Culpability and Punishment of Young Offenders}

BY:

ELIZABETH S. SCOTT

COLUMBIA LAW SCHOOL

N. DICKON RUPPUCI

UNIVERSITY OF VIRGINIA

JILL ANTONISHAK

UNIVERSITY OF VIRGINIA

JENNIFER T. DEGENNARO

UNIVERSITY OF VIRGINIA

This paper can be downloaded without charge from the

Social Science Research Network electronic library at:

http://ssrn.com/abstract $=959635$ 
Public Attitudes about the Culpability and Punishment of Young Offenders

Elizabeth S. Scott, Columbia Law School

N.Dickon Reppucci, University of Virginia

Jill Antonishak, University of Virginia

Jennifer T. DeGennaro, University of Virginia 


\section{Public Attitudes about the Culpability and Punishment of Young Offenders}

Over the past few decades, juvenile justice policy has been transformed from a regime that viewed most offenders as youngsters whose crimes were the product of immaturity into one that increasingly sees little difference between juveniles and adults who commit serious crimes. It is generally accepted that intense public concern about the threat of youth crime has driven this trend (Roberts, 2004). In response, politicians across the country have enacted legislation under which growing numbers of youths are prosecuted in criminal courts and sentenced to prison (Reppucci, 1999; Scott \& Steinberg, 2003; Snyder \& Sickmund, 1995). Today, in almost every state, youths who are 14 years of age (or younger) can be tried and punished as adults for a broad range of crimes (Sickmund, 2003; Griffin, Torbet, \& Szymanski, 1998).

Various opinion surveys have found public support generally for getting tougher on juvenile crime and punishing youths as harshly as their adult counterparts (Bureau of Justice Statistics [BJS] Sourcebook, 2003; Soler, 2001; Moore, 1994). Polls have also indicated public dissatisfaction with the juvenile courts, which are seen as responding too leniently to young offenders (Sprott, 1998; Hart, 1998). This survey evidence has reinforced the conventional wisdom that the recent reforms are compatible with public opinion and responsive to public pressure.

Although this account of public opinion and its impact on punitive policies has been widely accepted, it is puzzling because it represents a dramatic departure from legal policies and social attitudes toward children and adolescents in virtually every other context-- including 
policies and attitudes toward youth crime. The public apparently endorses laws under which young adolescents can be sentenced to long prison terms when they are too young to hold a job, drink, or even go out without their parents' permission (Juvenile Law Center, 2004; Scott, 2000). The presumption that youths are incapable of making mature decisions and should be protected from their own immature judgment defines the legal regulation of minors, apparently with widespread public support (Scott, Reppucci \& Woolard, 1995). Until quite recently, immaturity was assumed to mitigate criminal responsibility and punishment (Scott \& Steinberg, 2003; Zimring, 2000). The view that young offenders deserved less severe punishment than adults justified the separate juvenile justice system and persisted, seemingly with broad public support, throughout most of the last century (Zimring, 1978). Today, paternalistic attitudes toward youth that are deeply embedded in our law and culture seem to have little impact on public views or political responses in the context of youth crime regulation.

It might appear that the puzzle is easily solved. Changing public attitudes may be a predictable response to an increase in violent youth crime together with a perception that juvenile courts have been ineffective in protecting the public. It is well documented that the rates of violent crimes committed by juveniles (particularly homicides in which guns were used) rose rapidly beginning in the late 1980s (Zimring, 1998). In the wake of this trend, public alarm became an impetus for more punitive policies that both major political parties endorsed (Coen, 2005; Dao, 1996; Sorenson, 1995).

This explanation is plausible, but it suggests that public attitudes toward youth crime might have softened in response to the steady decline in the juvenile crime rate over the past decade (NCJJ, 2003; Torbet \& Szymanski, 1998). However, punitive reforms have continued 
despite lower juvenile crime rates. For example, after several years of declining crime rate, California voters in 2000 passed Proposition 21--mandating criminal prosecution of youths age 14 and older for a range of serious crimes. (McClain, 2000; Raymond, 2000). Passage of the initiative followed an intense media campaign by supporters emphasizing the threat of juvenile gangs (Roberts, 2004). Numerous surveys in the late 1990s suggested that Americans mistakenly believed that juvenile crime was increasing and that the public exaggerated the proportion of crime attributable to juveniles (Shephard, 2002; Soler, 2001; Zimring, 1998). The sources of these misperceptions are unclear, although sensational media coverage of high profile crimes is likely one factor (Kuran \& Sunstein, 1999). Young criminals have been depicted in the media as "superpredators," an image that was a far cry from the descriptions of wayward youth in an earlier era (DiIullio, 1995; Lindsay \& O’Higgins, 1970). It is possible that the public may view young offenders as adultlike, either because of visual images from television news or because the political rhetoric depicts them as calculating and mature criminals.

A more pernicious explanation of the public misperception and seemingly exaggerated fears posits that race plays a role in the public response to juvenile crime. Minority youths are disproportionately represented among the population of young criminals (Bishop \& Frazier, 1998; Office of Juvenile Justice \& Delinquency Prevention: Program Report, 1997). Fear of youth crime often has had racial overtones, as when public concern has focused on juvenile gangs, such as the African-American Crips and Bloods in Los Angeles (Mayer, 1993). Moreover, the research indicates that media portrayal of juvenile crime reinforces the public view that perpetrators of violent crime are African American (Dorfmann and Schiraldi, (2001); Gilliam \& Bales, 2001). A few studies suggest that conscious or unconscious racial stereotyping 
influences punitive public attitudes toward youth crime (Graham \& Lowery, 2004; Bridges \& Steen, 1998). However, much more research is needed to understand how the race of young offenders affects attitudes about youth crime.

Given the puzzling character of the punitive public attitudes toward youth crime, it is important to ask whether the conventional wisdom on this issue is accurate. Scrutiny of the sources of information about public opinion reveals that evidence about public attitudes is based largely on either responses to highly publicized crimes such as school shootings (or, in the case of Proposition 21, to an intense media campaign) or on mass opinion polls that typically ask a few simplistic questions (Cullen, Fisher, \& Applegate, 2000; Roberts \& Stalans, 1997). The former may reflect heightened emotional arousal and not stable preferences, while the latter may be superficial expressions that distort attitudes. In fact, evidence from a small body of recent research that seeks to probe more deeply into adults' attitudes toward juvenile crime suggests that the public response may be more complex than political rhetoric suggests. (Roberts, et. al., 2002; Stalans \& Henry, 1994; Schiraldi \& Soler, 1998). For example, several surveys have found public support for rehabilitation as a goal of juvenile justice policy (Roberts, 2004; Moon et al., 2000) and also for sanctions and programs that are alternatives to prison (Krisberg \& Austin, 1993). A few quite recent polls found public opposition to the juvenile death penalty, in contrast to earlier surveys (News-Star.Com Poll, 2003; Gallup Poll, 2002), and in 2005, the Supreme Court found the juvenile death penalty to be unconstitutional under the Eighth Amendment prohibition of cruel and unusual punishment, in part because of the developmental immaturity of juvenile offenders (Roper v. Simmons, 2005). Even respondents who advocate prison for young criminals favor separation from adult offenders (Roberts, 2004; Knowles, 
1980). However, the existing evidence is sketchy and points to the need for further research to develop an accurate and more nuanced picture. This is of critical importance since policymakers have justified punitive juvenile justice reforms on the basis of popular demand for tougher policies (Roberts, 2004).

The current study is an initial step toward this goal. It probed opinion about youth crime in what might be called a neutral setting, that is to say, not in response to a high profile crime or during a political campaign when the media focuses on the issue. The study used two methodologies, reflecting our view that gauging public attitudes through different techniques is likely to yield a more accurate picture than the standard public opinion poll alone. First, we employed a survey, which directly asked participants’ opinions about the minimum age of adult criminal prosecution for a broad range of crimes. Second, we designed a unique experimental technique in which participants were asked to respond to an individual offender who was described briefly and depicted (ostensibly) in a video clip of a robbery and also in a picture. The experimental technique, which is described in detail below, made it possible to explore whether the age, appearance of maturity and race of offenders affect attitudes about appropriate punishment and responsibility without asking about these variables directly. It is possible that participants may reveal attitudes indirectly in response to the study’s stimuli that they would not reveal directly (Graham \& Lowery, 2004). ,

The objective of our study was to determine the extent to which adults’ perceptions and attitudes about the culpability of young offenders and appropriate punishment for their crimes are influenced by age, race and appearance of the offenders. Specifically, the study is guided by the following hypotheses: 1.) Participants will perceive younger offenders as less psychosocially 
mature and criminally responsible than adult offenders. Participants will punish younger offenders less severely and perceive that younger offenders have greater potential for rehabilitation than older offenders. 2.) Participants will perceive African-American youth to be more psychosocially mature, more criminally responsible, and deserving of harsher punishment than Caucasian youth. 3) Participants will perceive youth who appear more physically mature to be more psychosocially mature, more criminally responsible, and deserving of harsher punishment than youth who appear as a typical youth of a given age.

\section{Study 1:}

\section{Method}

\section{Participants}

A racially and socioeconomically diverse sample of 604 male and female adults (51\% male) ages 21-96 ( $\mathrm{M}=40.7)$ participated in the study. Socioeconomic diversity was achieved by collecting data in multiple neighborhoods. $67 \%$ of these participants identified themselves as Caucasian, 27\% as African-American, and 6\% as Hispanic, Asian, or other. Demographic data on income, education, and political values were collected (see Table 1).

Stimulus Materials. Pilot studies were completed to assist in the development of two sets of stimulus materials. For the first set, participants evaluated multiple photos of AfricanAmerican and Caucasian youths, aged 12, 15, and 20, for attractiveness, “toughness,” and perceived age, in order to precisely match the pictures to be shown to participants. As a result of the photo-rating pilot work, two photos, one of an African-American and the other of a Caucasian 12-year-old, were selected because of their match to each other on attractiveness, toughness, and age appearance. Additional photos of these same youths at ages 15 and 20 were 
altered so that the features and clothing were similar in every instance. This process of morphing (age-enhancing) through computer technology was employed to insure equivalence. In order to test whether appearance of maturity affects perceptions of culpability, the study employed pictures of "typical” and "mature-looking” 12- and 15-year-olds. For this purpose, the morphed photos of the 15-year-olds were used as the mature-looking 12-year-olds, and the photos of the 20-year-olds were used as the mature-looking 15-year-olds (See Figure 1).

For the second set of materials, a 38-second video of an actual convenience store armed robbery that had been captured on a surveillance camera was used. Because the robber’s face was completely covered in a ski mask, it was impossible to discern the offender's age, gender, or race. In actuality, the voice on the original tape was that of a Caucasian female about 16 years of age and Because was easily altered electronically to sound like a Caucasian male at the three ages because the focus of investigation was adults’ perceptions of male offenders’ culpability. An identical recording of an African-American female voice was made and then altered to sound like an African-American male at the three ages. Voices were professionally enhanced, controlling for any possible tonal, pitch, or other voice inflections.

Before each participant viewed the video, the person was presented with a photo and told that it was the robber in the video, and the following descriptive vignette was heard as the person viewed the photo:

"Michael and two of his friends robbed a convenience store. This is actual footage from the security camera that shows Michael’s involvement in the robbery. His two friends are waiting outside the store. This is a picture of Michael taken a month before the crime. He is $(12,15,20)$ years old and is in the $\left(6^{\text {th }}\right.$ grade, $9^{\text {th }}$ 
grade, not applicable). [After the video is shown, the vignette continues.] The clerk was not injured in the robbery and Michael and his friends were picked up later for the crime.”

Measures

Michael's psychosocial maturity scale

After viewing the video, participants responded to questions about the offender's psychosocial maturity. This nine-question scale focused on participants' perceptions of how much Michael was able to appreciate the consequences of his actions and the impact of the crime on others (see Appendix for a complete set of the items). Participants responded on a 4-point scale, with 1 = "did not think about" to 4 = "thought a lot about." The nine items were averaged for an overall psychosocial maturity scale with higher scores representing greater psychosocial maturity. Cronbach's alpha for the psychosocial maturity scale was .82. (based on Scott, Reppucci, \& Woolard; Steinberg \& Cauffman concept of psychosocial maturity, but developed for the current study)]

\section{Michael's potential for rehabilitation, responsibility, and trial in adult court}

Three questions addressed Michael's future potential: 1) How likely is it that Michael can be rehabilitated? 2) How likely is it that Michael will outgrow his criminal behaviors? and 3) How likely is it that Michael will have a productive life? Participants responded on a 6-point Likert-type scale (with $1=$ very likely to $6=$ very unlikely). Higher scores indicate greater likelihood of rehabilitation. Participants answered a question about how responsible Michael was (with $1=$ fully responsible to $6=$ not at all responsible). Participants were also asked how much they agree with the statement "Michael should be tried in adult court for this crime" (with 
$1=$ strongly disagree to $6=$ strongly agree). Finally, participants were asked what sentence

Michael should receive for his crime. Participants could choose a community-based treatment or punishment (such as counseling, mental health services, house arrest, or community services) or incarceration in a juvenile facility or jail/prison.

General attitudes toward adult adjudication and punishment of juveniles

Participants were asked to provide the age at which they believed a youth should be tried and punished as an adult for ten crimes (murder, armed robbery, rape, burglary, assault, car theft, theft from a store, destruction of property, drug possession, and drug sale). Respondents circled the youngest age they would recommend adult adjudication and punishment for each crime, from a range of years provided (5 years to 21 years).

Procedure

Each participant was presented with one photo of a youth described as the perpetrator and then viewed the short video of the armed robbery of the convenience store. (The photo was either a "typical" or mature looking 12- or 15-year-old Caucasian or African-American male, or a typical looking 20-year-old African-American or Caucasian male.) After viewing the video, seeing the photo, and having the brief vignette read to him/her while the photo was concurrently shown on the computer screen, the participant was asked a series of questions about the offender's involvement in the crime, the offender's maturity and judgment (involving variables such as impulsivity, anticipation of consequences, peer influence, and capacity to assess risks), and the appropriate disposition/punishment. Participants were also asked general questions about adjudication and punishment of juveniles as adults as part of a larger measure of attitudes towards crime, and questions about appropriate minimum age of autonomy for multiple 
activities. Finally, demographic information on gender, race, SES (education), age, and political philosophy was collected.

The video and photo manipulation was administered individually using a personal computer because data were collected in various public places, including shopping and pedestrian malls, grocery stores, department stores (K-Mart), and laundromats. In several instances, participants were seen in rooms in the public library adjacent to a downtown pedestrian mall. Participants were paid \$10 for their time, which was approximately 20-25 minutes for the entire assessment.

To control for possible order effects, half of the sample saw the video vignette and answered questions about it followed by the questionnaire focusing on general attitudes about crime. The other half answered the general attitudes questionnaire first and then saw the video vignette. For the current study, the only questions analyzed from the general attitudes survey were those regarding adult adjudication and punishment for specific crimes. At the end of the study protocol, respondents recorded demographic data including their date of birth, race, highest level of education obtained, household income, and political orientation (Very Conservative, Somewhat Conservative, Moderate, Somewhat Liberal, or Very Liberal).

\section{Results}

Preliminary analyses demonstrated that the primary variables of interest met the assumptions of normality and linearity. We did not find any systematic pattern of effects related to the order in which participants completed the vignette-specific and general attitudes items.

First, we conducted two (age: 12- and 15-year old) by two (physically-mature and typical) ANOVA's to examine if there were any differences between the physically mature and 
typical looking offenders. There were no significant differences between these groups on our primary variables of interest (responsibility, psychosocial maturity, potential for rehabilitation, and transfer to adult court). Given the lack of differences, offenders were grouped by Michael's age rather than physical maturity.

Means and standard deviations for vignette-specific variables are presented in Table 2 by Michael’s age.

The effect of offender characteristics on perceptions of culpability and responsibility

Preliminary analyses revealed significant relationships between several demographic characteristics of participants and our variables of interest. Participants’ political values, race, gender, and education were significantly related to some of the outcome variables, but participants’ age was not. Given these associations, participants’ race, political beliefs, education, and gender were entered as covariates in the 2X2 ANCOVA's with dependent variables: 1) Perceptions of Michael's psychosocial maturity; 2) Michael's responsibility for the crime; 3) Michael's potential for rehabilitation; and 4) support for transferring Michael to adult court.

Table 3 provides a summary of the ANCOVA results, as well as significant post-hoc comparisons.: Contrary to our hypothesis, the offender's race failed to contribute significantly to the prediction of the outcome variables. However, after accounting for participant characteristics, the offender's age was a significant predictor of perceptions of Michael’s psychosocial maturity, responsibility for the crime, desirability of transfer to adult court, and his potential for rehabilitation. Although there were no significant age-related differences in participants' beliefs in Michael's potential for rehabilitation $(\mathrm{F}=2.11, \mathrm{p}=.12)$, there were 
differences in perceptions of Michael’s psychosocial maturity, responsibility, and whether he should be tried in adult court. Participants indicated that the 12-year old and the 15-year old were less psychosocially mature than the 20-year old $(F=6.68, p=.001)$, although they did not think that the 12-year old and the 15-year old differed in maturity. Participants clearly indicated that the 12-year old was significantly less responsible for the crime than both the 15-year old and the 20-year old ( $\mathrm{F}=5.10, \mathrm{p}=.006$ ), although there were no differences between the 15 and 20year old. Finally, participants were less likely to think that 12-year old Michael should be tried in adult court compared to15-year old Michael $(\mathrm{F}=9.13, \mathrm{p}=.003)$ [Note that 20-year old Michael could only be tried as an adult]. There were no significant interactions between Michael's age and race.

Predicting sentencing from Michael's and participants' characteristics

A forward stepwise logistic regression was conducted to examine prediction of type of sentencing from Michael's age and race and the participant's race and political affiliation. Participants were given the option of a community-based treatment or punishment (such as counseling, mental health services, house arrest, or community services) or incarceration in a juvenile facility or jail/prison. Michael's age was not related to likelihood of incarceration versus a community-based sentencing, although it was related to likelihood of incarceration in a juvenile facility versus jail or prison. Only the participant's political affiliation was a significant predictor of the likelihood of sentencing Michael to a correctional facility or a community-based sentencing option. Higher levels of political conservatism were linked to a greater likelihood of incarcerating Michael $\left(\beta=-.32 ; \chi^{2}=14.29 ; p=.00\right)$. Only a small percent of participants suggested sentencing the adolescent Michael to jail (4\% and 11\% for the 12 and 15- year old, 
respectively).

\section{Adult adjudication and punishment}

Participants utilized the full scale for items dealing with minimum age of adult adjudication and sentencing with some participants supporting adult adjudication and sentencing to jail or prison for youths 5 years of age, and others supporting a minimum age of 21 . Participants endorsed lower ages of adult adjudication for more serious and violent crimes, with a mean age for all crimes of approximately 16. Table 4 shows the mean age of adult adjudication for each crime. It also provides the mode, which in all cases but murder is 18 years of age. Means are also provided for conservatives (combined "very" and "somewhat" conservative), moderates, and liberals (combined "very” and “somewhat” liberal).

\section{Study 2}

The participant responses in study 1 were less punitive than we had expected. One hypothesis for these findings was that the pictured youths, although matched to one another for toughness and attractiveness, were not representative of actual juvenile offenders because they were not sufficiently tough or unattractive. To test this hypothesis, a second study was undertaken, with only one change. In Study 2, 85 participants (age range 21 - 82, $\mathrm{M}=38.2$; 52\% male; 68\% Caucasian, 24\% African-American, and 8\% Hispanic, Asian, or other) saw the same video, but the pictures of the youth presented were of professionally hired 15-year-olds who were photographed to look “tough.” (See Figure 2) The youth was described as either 12 or 15 years of age. Because in Study 1 no differences were found between the picture of a 15 year old when it was labeled as showing a 12-year-old and the actual picture of a 12-year-old, age, rather than physical appearance, seemed to dictate responses. As such, we used only one photo 
each of the African-American and Caucasian youth but varied the reported age. Participants in study 2 were not significantly different from participants in study 1 on any of the demographic characteristics.

Significant differences between the pictures of the "thuggish-looking" youths and those in Study 1 were achieved: Participants rated Caucasian and African American "thuggish" Michael as less attractive $(\mathrm{F}(1,767)=34.4, \mathrm{p}=.00)$ tougher looking $(\mathrm{F}(1,780)=34.91, \mathrm{p}=.00)$, and more likely to be from a lower social class $(\mathrm{F}(1,770)=45.07, \mathrm{p}=.00)$. Despite these differences in appearance, participants in Study 2 did not differ in their perceptions of Michael’s psychosocial maturity, likelihood of rehabilitation, or desire to adjudicate in adult court. The only significant group difference for the vignette items was participants’ response to the seriousness of the crime; participants who saw the "thuggish" pictures of Michael thought the crime was more serious than participants in Study $1(\mathrm{~F}(1,787)=4.49, \mathrm{p}=.01)$. Again, there were no significant race differences.

\section{Discussion}

This study individually assessed hundreds of community adults, probing their attitudes about whether the criminal responsibility and appropriate punishment of young offenders are linked to offenders' age, race and developmental immaturity. Unlike previous research, which typically has explored public opinion about these issues by asking only general questions, this study also used a sophisticated methodology involving a video recording and photos to direct each participant's attention to an individual perpetrator actually involved in a serious crime. The study also probed general attitudes about processing youths in adult criminal court across a range of offenses. It explored links between attitudes expressed and the race and physical appearance 
of the offender without directly adverting to these variables and examined participant attitudes in relation to their own race, education, political philosophy, age and gender.

Three major findings emerged: 1) Community adults endorse the view that the criminal choices of young offenders are influenced by their developmental immaturity and attribute more responsibility for the criminal act to older actors; 2) there is a relatively strong preference among the public for differential treatment of juvenile and adult offenders, as evidenced by disapproval of adult court adjudication and punishment both generally and in response to Michael; and 3) attitudes about culpability and punishment did not appear to be affected by the perpetrator's race, physical maturity, or "toughness.”

Although conventional wisdom holds that popular demand is the driving force behind the recent juvenile justice reforms, our results challenge the assumption that the public supports punitive policies for young offenders. Our participants supported the view that young offenders are less psychosocially mature and less responsible than their adult counterparts and that even those young offenders who commit serious crimes should not be subject to adult incarceration. Moreover, we did not find support for policies of shifting the boundary of criminal court adjudication so that young teens can be tried as adults. Specifically, we found little support for the recent statutory reforms under which 14 year olds in most states can be tried as adults for many serious crimes, including property offenses and drug selling, and, in many jurisdictions, 12 year olds can be criminally charged with murder, rape and armed robbery. Although lawmakers argue that the public has insisted upon these reforms, our participants expressed more lenient attitudes_-both in general and in response to Michael, the armed robber in the video. Few supported the adult prosecution of 12 year olds even for murder, and the mean minimum age of 
transfer across crimes selected by our participants was 16, the typical minimum age of transfer under “traditional” (pre-reform) statutes. In general, public opinion as expressed in this study does not conform to the perceptions of politicians who have substantially restricted the boundaries of juvenile court jurisdiction.

The findings suggest a public that endorses immaturity as mitigating culpability- a view that would support more lenient attitudes toward punishment of youths. Advocates for punitive policies have dismissed the notion that developmental immaturity is relevant to criminal punishment with the adage, “Adult time for adult crime” (Ellis, 1993). In contrast, this study reveals public awareness of the links between youth and reduced criminal responsibility. The results indicate that adults recognize the psychosocial immaturity of teens, viewing the decision of an adolescent armed robber as involving less foresight of the negative consequences of his conduct than the choice of his adult counterpart. This comports with the traditional view that young criminals are less culpable than adults, in part, because they act impulsively and do not fully anticipate the consequences of their harmful conduct (Scott \& Steinberg, 2003). Thus, when politicians discount the mitigating character of immature judgment in their political rhetoric about youth crime, they may be misreading public opinion.

An important issue in understanding public opinion about youth crime is whether the race of young offenders influences attitudes. No previous study has sought to probe racial attitudes by presenting stimuli of youths engaged in very serious criminal activity, matched for attractiveness, toughness, appearance of maturity and seriousness of offense, while differing only in race. Contrary to our expectations, we found no attitude differences relating to the race of the offender. That our participant responses did not vary in response to the race of the 
offender depicted in the photo might be explained in several ways. The first and most transparent explanation is that (these) adults do not consider the race of juvenile offenders in responding to their criminal behavior. However, some empirical evidence suggests that racial biases do influence attitudes in this area (Graham, 2002; Males \& MacCallair, 2000; Bishop \& Frazier, 1998). Thus, we must consider another explanation- that participants guarded against displaying racial bias when presented with a racial stimulus. Contemporary social norms strongly reject racial prejudice, and most individuals would not want to reveal racial bias. Although no verbal mention of the offender's race was offered, the picture of African American Michael may have alerted participants who saw it to the fact that the study was probing racial attitudes. Some researchers have found that racial bias is revealed through unconscious stereotyping, that may be consciously resisted if race is made salient (Sommers \& Ellsworth, 2003; Graham, 2002; Bridges \& Steen, 1998). The picture of an African American youth may have made race salient and triggered a cautious response in those participants presented with this stimulus. 
What explains the differences between our findings and the account of public attitudes about juvenile crime and criminals that generally has been offered in the political arena? In part, the more lenient attitudes expressed by our subjects may reflect the fact that our survey was conducted quite recently. Punitive attitudes may be subsiding because the public has gradually become aware that youth crime no longer represents the serious threat to public safety that it did in the 1990s. That public perceptions should lag behind behavior change in this area is probably to be expected. In a related context, public attitudes for and against the death penalty have followed but lagged behind violent crime trends over the past half century, such that a decline in violent crime has been followed eventually by declining support for the death penalty (Gross \& Ellsworth, 2003; Gross, 1998). A similar pattern may be at work here. Residual paternalistic attitudes about youth may resurface when the perception that young criminals represent a threat to public safety ebbs. Moreover, attitude change may also reflect public awareness of the recent punitive reforms, which have received widespread media coverage (Cullen, Fisher, \& Applegate, 2000; Roberts \& Stalans, 1997). Public expressions of disapproval of the life sentence imposed on Lionel Tate for a murder committed at age 12 (a sentence that was later reversed) may be representative of a broader backlash against punitive policies (Scott \& Steinberg, 2003). In part, our participants may be protesting justice reforms that they think have gone too far.

Another feature of this study may be important in explaining our findings. As noted, public opinion in this area is often gauged either through abbreviated polls that tend to provide sketchy information or in response to highly publicized violent juvenile crimes. In the latter context, the perception that young criminals threaten society can become exaggerated. Cognitive psychologists have familiarized us with the availability heuristic, a mechanism 
through which the magnitude of risks that are vivid and readily brought to mind becomes exaggerated in our perceptions (Kahneman \& Tversky, 1982). When a violent crime such as a school shooting gets intense media coverage, its salience may become heightened and distorted in the public imagination (Mulvey \& Cauffman, 2001). In contrast, our participants were invited to reflect on youth crime in a neutral context. Moreover, although the video clip depicted an actual violent crime for which older adolescents are likely to be subject to criminal court adjudication in every state, it was made clear that no one was physically harmed. It is plausible that our participants’ expressed attitudes represent less emotional and perhaps less transient policy preferences than those that are gleaned in response to horrendous crimes.

\section{Policy implications}

Any lessons the study may offer for policy formation must be qualified by its limitations. Because the participants were all from a single geographic locality, the generalizability of the findings is unclear. Although we statistically controlled for political values, the fact that more of the participants were liberals than conservatives may have had an impact on the results. Moreover, our participants were more highly educated than a comparable national sample, which for some outcomes was associated with support for more lenient attitudes. However, both of these variables were controlled in the analyses.

At a minimum, these findings of our study challenge the political rationale for the recent punitive policy reforms, suggesting that politicians may base have somewhat distorted understanding about public attitudes toward juvenile crime. Although the public sometimes responds with anger to publicized juvenile crimes and appears to strongly support "get-tough” policies, these reactions may be transient. As the perception of threat fades, public enthusiasm 
about legislation enacted in response to community fears may decline. One lesson of our study may simply be that legislative reform of youth crime policy should not be undertaken in haste in the midst of the furor surrounding a highly publicized violent crime. Caution and deliberation may result in policies that are more satisfactory (and more reflective of public attitudes) over the long term. Our study also suggests that the political risk that policymakers face in responding cautiously to public pressure is not as great as they might surmise. When more neutral conditions prevail, traditional paternalistic attitudes toward youths may resurface as an influence on public views about youth crime policy.

Punitive policies carry have substantial economic and social costs to the public as well as to the young offenders, costs that lawmakers must believe are outweighed by the public benefits. Among those benefits are public safety and satisfaction based on perceptions about enhanced security or appropriate retribution (Brown, 2003). Our study suggests that the public may be receptive to research evidence indicating that public protection may be better served by juvenile correctional dispositions than by adult punishment (Fagan, Kupchik, \& Liberman, 2003; Fagan, 1997). Moreover, when the costs of punitive policies are made explicit, enthusiasm for punitive policies often wanes. For example, one study found that public support for imprisoning juveniles declines when concrete information about the financial costs is provided and when people are reminded that imprisoned youths will return to the community (Sprott, 1998). Particularly in an era when juvenile crime rates are stable or declining, the public may support less costly policies under which most young offenders are dealt with in a separate juvenile system that is designed to maximize their prospects for productive adulthood (Brown, 2003). 
In conclusion, this study has both scientific significance and policy relevance. From the scientific perspective, it was designed to investigate attitudes about the culpability and punishment of young offenders and the extent to which these attitudes are influenced by an offender’s age, physical maturity, and race, and to do so by using a more sophisticated methodology than has previously been employed in measuring public attitudes in this domain. It has succeeded in both of these goals. From the policy perspective, public opinion is an important influence on lawmakers' decisions about the regulation of juvenile crime. Politicians make assumptions about public attitudes in this context on the basis of casual observation, opinion polls and their own biases. We maintain that a more accurate understanding of public attitudes based on systematic research will support better public policy. The findings of this study can contribute to a more thoughtful and nuanced public discussion of the appropriate responses to youth crime. 


\section{References}

Bernard, J.L. (1979). Interaction between the race of the defendant and that of jurors in determining verdicts. Law and Psychology Review, 5, 103-111.

Bishop, D.M., \& Frazier, C.E. (1998). The influence of race in juvenile justice processing. U.J. Res. Crime and Delinquency 25, 242-258.

Brown, D. K.(2005). Cost-benefit analysis in criminal law. California Law Review, 92, 325-372.

Bureau of Justice Statistics Sourcebook of Criminal Justice Statistics 157. (1990). In Flanagan, T., \& Maguire, K. (Eds.). Washington, D.C.: U.S. Department of Justice.

Bureau of Justice Statistics. (1995). Washington, D.C.: U.S. Department of Justice.

Bureau of Justice Statistics Sourcebook of Criminal Justice Statistics. (2003). Washington, D.C.: U.S. Department of Justice.

Bridges, G.S., \& Steen, S. (1998). Racial disparities in official assessments of juvenile offenders: Attributional stereotypes as mediating mechanisms. American Sociological Review, 63(554), 561-64.

Butterfield, F. (1995). All God's children: The Bosket family and the American tradition of violence. ( $1^{\text {st }}$ ed.). New York: Knopf.

Coen, J. (2005, Mar. 27). Juvenile sentencing law could seal a fate. Chicago Tribune, p. 1.

Cullen, F., Fisher, B., \& Applegate, B. (2000). Public opinion about punishment and corrections. In M. Tonry (Ed.), Crime and justice: A review of research (Vol., 27, pp.1-80), Chicago: University of Chicago Press.

Dao, J. (1996, Dec. 10). New York’s top democrat takes a tougher stance on juvenile crime. New York Times, p. A5. 
Devine, P.G. \& Elliot, A.J. (1995). Are racial stereotypes really fading? The Princeton trilogy revisited. Personality and Social Psychology Bulletin, 21, 1139-1150.

DiIulio, Jr., J. The Coming of the super-predators, Weekly Standard, Nov. 27, 1995.

Dorfman, L. \& Schiraldi, V. (2001). Off balance: Youth, race and crime in the news. Washington D.C.: Building Blocks for Youth Initiative.

Ellis, V. (1993, Jan. 15). Lungren to seek lower age for trial as adult. L.A. Times, p. A3.

Ellsworth, P.C., \& Gross, S. (1994). Hardening of the attitudes: Americans' views on the death penalty. Journal of Sociological Issues, 50, 21.

Fagan, J. (1997). The comparative advantages of juvenile versus criminal court sanctions on recidivism among adolescent felony offenders. Law and Policy, 18, 77-115.

Fagan, J., Kupchik, A., \& Liberman, A. (2003). Be careful what you wish for: The comparative impacts of juvenile versus criminal court sanctions on recidivism among adolescent felony offenders. Research Paper. New York: Columbia Law School. Available at http://ssrn.com/abstract=491202.

Feldman, S. \& Quatman, T. (1988). Factors influencing age expectations for adolescent autonomy: A study of early adolescents and parents. Journal of Early Adolescence, 8, $325-343$.

Firestone, D. (1999, Apr. 11). Arkansas tempers a law on violence by children. New York Times, p. 20.

Fox, S. (1970). Juvenile justice reform: An historical perspective. Stanford Law Review, 22, $1187-1240$. 
Gaertner, S.L. \& Dovidio, J.F. (1986). The aversive form of racism. In S.L. Gaertner \& J.F. Dovidio (Eds.), Prejudice, discrimination, and racism (pp. 61-89). Orlando: Academic Press.

Gilliam, F.D., Jr. \& Bales, S.N. (2001). Strategic frame analysis: Reframing America’s youth. Social Policy Reports, 15, 2-24.

Goldman, J. (1997, May 31). Sex offender guilty of killing Megan Kanka. L.A. Times, p. A1.

Graham, S. \& Lowery, B. (2004). Priming unconscious racial stereotypes about adolescent offenders. Law and Human Behavior, 28(5), 483-504.

Griffin, P., Torbet, P., \& Szymanski, L. (1998). Trying juveniles as adults in criminal court: An analysis of state transfer provisions. Washington, D.C.: U.S. Office of Juvenile Justice and Delinquency Prevention.

Gross, S.R. (1998). Update: American public opinion on the death penalty-It’s getting personal. Cornell Law Review, 83, 1448-75.

Gross, S.R., \& Ellsworth, P.C. (2003). Second thoughts: Americans’ views on the death penalty at the turn of the century. In S.P. Garvey (Ed.), Beyond repair?: America's death penalty (pp.7-57). Durham: Duke University Press.

Hart, T. (1998). Causes and consequences of juvenile crime and violence: Public attitudes and question-order effect. American Journal of Criminal Justice, 23, 129-43.

Hough, M., \& Roberts, J.V. (2003). Institute for Criminal Policy Research Study. London: King's College School of Law.

Juvenile Law Center Age Requirements Fact Sheet. (2004). Retrieved May 30, 2005, from http://www.jlc.org/agerequirements/default.php/. 
Knowles, J. (1980). Ohio citizen attitudes concerning crime and criminal justice. (2nd ed.). Akron: Ohio Statistical Analysis Center-Office of Criminal Justice Services.

Krisberg, B., \& Austin, J. (1993). Reinventing juvenile justice. Newbury Park: Sage.

Krueger, J. (1996). Personal beliefs and cultural stereotypes about racial characteristics, Journal of Personality and Social Psychology, 71, 2-24.

Kuran, T., \& Sunstein, C.R. (1999). Availability cascades and risk regulation. Stanford Law Review, 51, 683-768

Levine, M., \& Levine, A. (1970). A social history of helping services: Clinic, court, school, and community. New York: Appleton-Century-Crofts.

Lindsay, B.B., \& O’Higgins, H.J. (1909). The Beast, 133, 82-83. Seattle: University of Washington Press. Reprinted in 1970.

Males, M., \& MacCallier, D. (2000). The color of justice: An analysis of juvenile adult court transfers in California. Washington, D.C.: Justice Policy Institute for the Building Blocks for Youth Initiative.

Mayer, J.J. (1993). Individual moral responsibility and the criminalization of youth gangs. Wake Forest Law Review, 28, 943-986.

McLain, J. (2000, Mar. 16). System bracing for kids in adult courts. Ventura County Star, p. A1.

Moon, M., Sundt, J., Cullen, F., \& Wright, J. (2000). Is child saving dead? Public support for juvenile rehabilitation. Crime and Delinquency, 46, 38-60.

Moore, D.W. (1994, Sept.). Majority advocate death penalty for teenage killers. GallupPoll Monthly, pp. 2-3. 
Mulvey, E.P., \& Cauffman, E. (2001). The inherent limits of predicting school violence. American Psychologist, 56(10), 797-802.

Justice Reform Initiatives in the States: 1994-1996 Program Report 4. (1997). Washington, D.C.: Office of Juvenile Justice and Delinquency Prevention.

Raymond, S. (2000). From playpens to prisons: What the Gang Violence and Juvenile Crime Prevention Act of 1998 does to California’s juvenile justice system and reasons to repeal it. Golden Gate University Law Review, 30, 233-284.

Reppucci, N. D. (1999).Adolescent development and juvenile justice. American Journal of Community Psychology, 27, 307-326.

Roberts, J.V., \& Stalans, L. (1997). Public opinion, crime, and criminal justice. Boulder: Westview.

Roberts, J.V., Hough, M., Indermaur, D., \& Stalans, L.S. (2000). Penal populism and public opinion: Lessons from five countries. Oxford: Oxford University Press.

Roberts, J.V. (2004). Public opinion and youth justice. In M. Tonry \& A.N. Doob (Eds.), Youth crime and youth justice: Comparative and cross-national Perspectives, 31 (pp. 495542). Chicago: University of Chicago Press.

Roper v. Simmons, 541 U.S. 1040 (2005).

Schiraldi, V., \& Soler, M. (1998). The will of the people? The public's opinion of the Violent and Repeat Juvenile Offender Act of 1997. Crime and Delinquency, 44, 590-601.

Scott, E.S., Reppucci, N. D., \& Woolard, J. S. (1995). Evaluating adolescent decision-making in legal contexts. Law and Human Behavior, 19(3), 221-244.

Scott, E.S. (2000). The legal construction of adolescence. Hofstra Law Review, 29(2), 547-98. 
Scott, E.S., \& Steinberg, L. (2003). Blaming youth. Texas Law Review, 81(3), 800-40.

Shephard, Jr., R.E. (2002). Recapturing the child in adult court. Criminal Justice,16, 58-61.

Sickmund, M. (2003). Juveniles in court, 6-10. Washington, D.C.: U.S. Department of Justice.

Snyder, H., \& Sickmund, M. (1995). Juvenile offenders and victims: National report.

Washington, D.C.: Office of Juvenile Justice and Delinquency Prevention.

Soler, M. (2001). Public opinion on youth, crime, and race: A guide for advocates. Retrieved May 30, 2005 on Building Blocks for Youth website: www.buildingblocksforyouth.org.

Sommers, S.R. \& Ellsworth, P.C. (2003). How much do we really know about race and juries?: A review of the social science theory and research. Chicago Kent Law Review, 78, 9971031.

Sorenson, J. (1995, Dec. 10). Pataki plan on juvenile offenders includes longer sentences in adult jails. Buffalo News, p. A16.

Sprott, J. (1998). Understanding public opposition to a separate youth justice system. Crime and Delinquency, 44, 399-411.

Stalans, L., \& Henry, G. (1994). Societal views of justice for adolescents accused of murder. Law and Human Behavior, 18(6), 675-96.

Steinberg, L., \& Scott, E.S. (2003). Less guilty by reason of adolescence: Developmental immaturity, diminished responsibility, and the juvenile death penalty. American Psychologist, 58(12), 1009-1018.

Torbet, P., \& Syzmanski, L. (1998, Nov.). State legislative responses to violent juvenile crime: 1996-97 Update, Juvenile Justice Bulletin. Washington, D.C.: Office of Juvenile Justice and Delinquency Prevention, pp. 1-2. 
Tversky, A., \& Kahneman, D. (1982). Judgment under uncertainty: heuristics and biases. In D. Kahneman, P. Slovic, \& A. Tversky (Eds.), Judgment under uncertainty: Heuristics and biases, (pp. 3-23). Cambridge: Cambridge University Press.

U.S. Department of Justice (1999). Twenty-first century law enforcement and public safety act. Available at http://permanent.access.gpo.gov/websites/usdojgov/archive/dag/pubdoc/21st_Century.pd $\mathrm{f}$

Wagman, M.T. (2000). Innocence lost in the wake of Green: The trend is clear-If you are old enough t do the crime, then you are old enough to do the time. Catholic University Law Review, 49, 643-679.

Zimring, F. E. (1978). Confronting youth crime: Twentieth century fund task force on sentencing policy toward young offenders. New York: Holmes \& Meier Publishers.

Zimring, F. (1998). American youth violence. New York: Oxford University Press.

Zimring, F. (2000). Penal proportionality for the young offenders: Notes on immaturity, capacity, and diminished responsibility. In T. Grisso \& R.G. Schwartz (Eds.). Youth on trial: A developmental perspective on juvenile justice (pp. 271-91). Chicago: University of Chicago Press. 
Appendix

Psychosocial maturity scale ( 1 = Did not think at all; 4 = Thought a lot)

- How much did Michael think about the negative consequences or risks of committing this crime?

- How much did Michael think about the positive consequences or benefits of committing this crime?

- How much did Michael think about the impact of his behavior on the clerk?

- How much did Michael think about the impact of his behavior on his family?

- How much do you think Michael and his friends planned this crime in advance?

- How much did Michael think about whether he might get hurt?

- How much did Michael think about whether someone else might get hurt?

- How much did Michael think about getting caught?

- How much did Michael think about getting punished? 
Table 1.

Participant Demographic Characteristics

\begin{tabular}{l|l}
\hline Income: & Percentage \\
\hline$<\$ 10,000$ & 16.8 \\
10,000-24,999 & 23.6 \\
25,000-39,999 & 22.9 \\
40,000-54,999 & 12.8 \\
55,000 and higher & 25.0 \\
& \\
Education: & Percentage \\
Some High School & 7.0 \\
High School Degree (or & 19.0 \\
GED) & \\
Some College & 24.0 \\
Associates Degree & 6.1 \\
Bachelor's Degree & 17.4 \\
Some Grad Education or & 25.7 \\
Degree & \\
Political values: & \\
Very Conservative & 6.6 \\
Somewhat Conservative & 16.6 \\
Moderate & 36.0 \\
Somewhat Liberal & 27.5 \\
Very Liberal & 13.3 \\
\hline
\end{tabular}


Table 2.

Vignette-Specific Variable Item Means and Age-related ANOVA’s

\begin{tabular}{lcll}
\hline \multicolumn{1}{c}{ Variable (Scale) } & $\begin{array}{l}\text { Mean (SD) } \\
\text { for 12-year } \\
\text { old }\end{array}$ & $\begin{array}{l}\text { Mean (SD) } \\
\text { for 15-year } \\
\text { old }\end{array}$ & $\begin{array}{l}\text { Mean (SD) } \\
\text { for 20 year } \\
\text { old }\end{array}$ \\
\hline $\begin{array}{l}\text { Michael's psychosocial maturity } \\
(1-4)\end{array}$ & $1.88(.57)$ & $1.87(.53)$ & $2.09(.63)$ \\
$\begin{array}{l}\text { Michael's potential for } \\
\text { rehabilitation (1-6) }\end{array}$ & $2.47(1.10)$ & $2.58(.99)$ & $2.71(1.03)$ \\
$\begin{array}{l}\text { Michael's responsibility (1-6) } \\
\text { Agreement to transfer Michael a }\end{array}$ & $2.09(1.21)$ & $1.87(1.08)$ & $1.70(1.16)$ \\
$(1-6)$ & $2.49(1.81)$ & $2.98(1.83)$ & N/A \\
\hline
\end{tabular}

Note: Scale anchors for these items sometimes varied by the content of the question, however the lowest endpoint typically represented disagreement or lack of the quality asked about the item (i.e., 1 = Did not think at all to 4 = Thought $A$ lot).

${ }^{a}$ Note: This item was answered by participants in the 12- and 15-year-old conditions only. 
Table 3.

Effects of participant demographics and offender characteristics on culpability and psychosocial maturity

\begin{tabular}{llll}
$\beta$ & $\Delta \mathrm{R}^{2}$ & $\Delta \mathrm{F}$ & $\mathrm{p}$ value for $\Delta \mathrm{F}$ \\
\hline
\end{tabular}

Michael's psychosocial maturity

Step 1: Participant demographics ${ }^{\mathrm{a}}$

Race

Political Values

Education

Gender

Step 2: Michael's age

Step 3: Michael's race

Michael's responsibility

Step 1: Participant demographics ${ }^{\mathrm{a}}$

Race

Political Values

Education

Gender

Step 2: Michael's age

Step 3: Michael's race

Transfer Michael to adult court

Step 1: Participant demographics ${ }^{\mathrm{a}}$

Race

Political Values

Education

Gender

Step 2: Michael's age

Step 3: Michael's race

Michael's potential for rehabilitation

Step 1: Participant demographics ${ }^{\mathrm{a}}$

Race

Political Values

Education

Gender

Step 2: Michael's age

Step 3: Michael's race $\begin{array}{lll}.11 & 16.19 \quad .00\end{array}$

$.18^{* *}$

$.20 * *$

.04

$-.12 * *$

$\begin{array}{llll}.10 * * & .01 & 6.56 & .01\end{array}$

$\begin{array}{llll}.04 & .00 & .93 & .34\end{array}$

$-.11^{*}$

$.19 * *$

$-.09 *$

.03

$\begin{array}{llll}-.12 * * & .02 & 8.87 & .00\end{array}$

$\begin{array}{llll}-.05 & .00 & 1.22 & .27\end{array}$

$\begin{array}{lll}.05 & 8.83 \quad .00\end{array}$

.00

$\begin{array}{lll}.09 & 10.09 \quad .00\end{array}$

$-.15^{*}$

$-.17 * *$

$-.15 * *$

$\begin{array}{llll}.13 * * & .02 & 8.41 & .00\end{array}$

$\begin{array}{llll}.01 & .00 & 1.53 & .90\end{array}$

$\begin{array}{lll}.03 & 4.63 \quad .00\end{array}$

$.16^{* *}$

$-.10^{*}$

.03

$-.02$

$\begin{array}{llll}.08 * & .01 & 3.91 & .04\end{array}$

$\begin{array}{llll}-.05 & .003 & 1.58 & .19\end{array}$

Table 4. 
Minimum Ages for Adult Adjudication and Sentencing

\begin{tabular}{lcccccc}
\hline & Mean & SD & Mode & $\begin{array}{l}\text { Conservative } \\
\text { mean }\end{array}$ & $\begin{array}{l}\text { Moderate } \\
\text { Mean }\end{array}$ & $\begin{array}{l}\text { Liberal } \\
\text { mean }\end{array}$ \\
\hline Murder & 15.13 & 3.05 & 16 & 14.46 & 14.96 & 15.70 \\
$\begin{array}{l}\text { Armed robbery of a person } \\
\text { Rape }\end{array}$ & 15.49 & 2.95 & 18 & 14.57 & 15.50 & 16.03 \\
$\begin{array}{l}\text { Burglary } \\
\text { (breaking \& entering) }\end{array}$ & 15.11 & 3.00 & 18 & 14.36 & 14.98 & 15.68 \\
$\begin{array}{l}\text { Assault resulting in an } \\
\text { injury }\end{array}$ & 15.89 & 2.86 & 18 & 15.13 & 15.62 & 16.60 \\
$\begin{array}{l}\text { Car theft } \\
\text { Theft from a store }\end{array}$ & 15.61 & 2.93 & 18 & 14.87 & 15.37 & 16.27 \\
$\begin{array}{l}\text { Destruction of property } \\
\text { Drug possession }\end{array}$ & 15.97 & 2.81 & 18 & 15.31 & 15.68 & 16.65 \\
Drug sale & 16.16 & 2.89 & 18 & 15.65 & 15.78 & 16.79 \\
& 16.33 & 2.84 & 18 & 15.38 & 15.76 & 16.85 \\
$\begin{array}{l}\text { Overall Adult Adjudication } \\
\text { Mean }\end{array}$ & 15.97 & 2.97 & 18 & 18.59 & 15.99 & 17.12 \\
\hline
\end{tabular}


Figure caption

Figure 1. Photo stimuli. Top row (left to right): 12-year old Caucasian; 15-year old and “mature” 12-year old Caucasian; 20-year old and "mature” 15-year old Caucasian; Bottom row (left to right): 12-year old African-American, 15-year old and “mature” 12-year old AfricanAmerican, 20-year old and “mature” 15-year old African-American. 
Figure 2. Photo stimuli for study 2. 